\title{
Commentary \\ Fatal attraction: why breast cancer cells home to bone
}

\author{
Lorenz C Hofbauer ${ }^{1}$, Tilman Rachner ${ }^{2}$ and Shiv K Singh ${ }^{2}$
}

\begin{abstract}
1'Division of Endocrinology, Diabetes, and Bone Diseases, Department of Medicine III, Technical University, D-01307 Dresden, Germany
2Department of Medicine, Philipps-University, D-35033 Marburg, Germany
\end{abstract}

Corresponding author: Lorenz C Hofbauer, lorenz.hofbauer@uniklinikum-dresden.de

Published: 25 January 2008

This article is online at http://breast-cancer-research.com/content/10/1/101

(c) 2008 BioMed Central Ltd
Breast Cancer Research 2008, 10:101 (doi:10.1186/bcr1848)

osteoclastic activity, including osteoporosis, rheumatoid arthritis, and bone metastases.

Earlier studies suggested that RANKL may be the long sought-after osteoclast activating factor, the critical factor expressed by breast cancer cells that functions as the stem cell factor for osteoclasts (Figure 1) [5]. When challenged by PTHrP, the human breast cancer cell line MCF-7 expressed RANKL, enhanced osteoclastic activity, and caused skeletal lesions and hypercalcemia after injection into mice [5]. Another human breast cancer cell line, MDA-MB-231, spontaneously expressed RANKL and grew bone metastases when transferred into susceptible mice [6]. Of note, skeletal lesions in these mice were reduced after blockade of RANKL by an OPG analogue [6]. These studies indicated that a local increase of the RANKL-to-OPG ratio is key for skeletal growth of breast cancer metastases and a potential target for therapeutic intervention. Other local factors released from bone matrix by osteoclasts or directly produced by osteoblasts, such as PTHrP, IL-6, TGF- $\beta$ and TGF superfamily members as well as activators and inhibitors of the Wnt signalling pathway, can directly modulate tumour biology of skeletal metastases. This involves direct receptor-mediated effects and paracrine effects converging at the RANKL/OPG level.

The RANKL/RANK pathway may direct breast cancer cells to preferentially migrate into bone, the crucial requirement and initial step for skeletal metastasis. Epithelial cells from normal mammary glands express RANK, and RANKL-RANK signalling is required for the development of lactating mammary glands during pregnancy [7]. Both RANKL- and RANKdeficient mice lack lactating mammary glands and cannot feed their off-spring [7]. Based on high constitutive RANK expression in breast cancer specimens and cell lines, recent data now indicate that the RANK expression status of cancer cells determines whether tumours predominantly migrate into bone, where the corresponding ligand RANKL is abundantly

$\mathrm{IL}=$ interleukin; OPG = osteoprotegerin; PTHrP = parathyroid hormone-related peptide; RANK = receptor activator of NF- $\mathrm{KB} ; \mathrm{RANKL}=\mathrm{RANK}$ ligand; TGF $=$ transforming growth factor. 
Figure 1
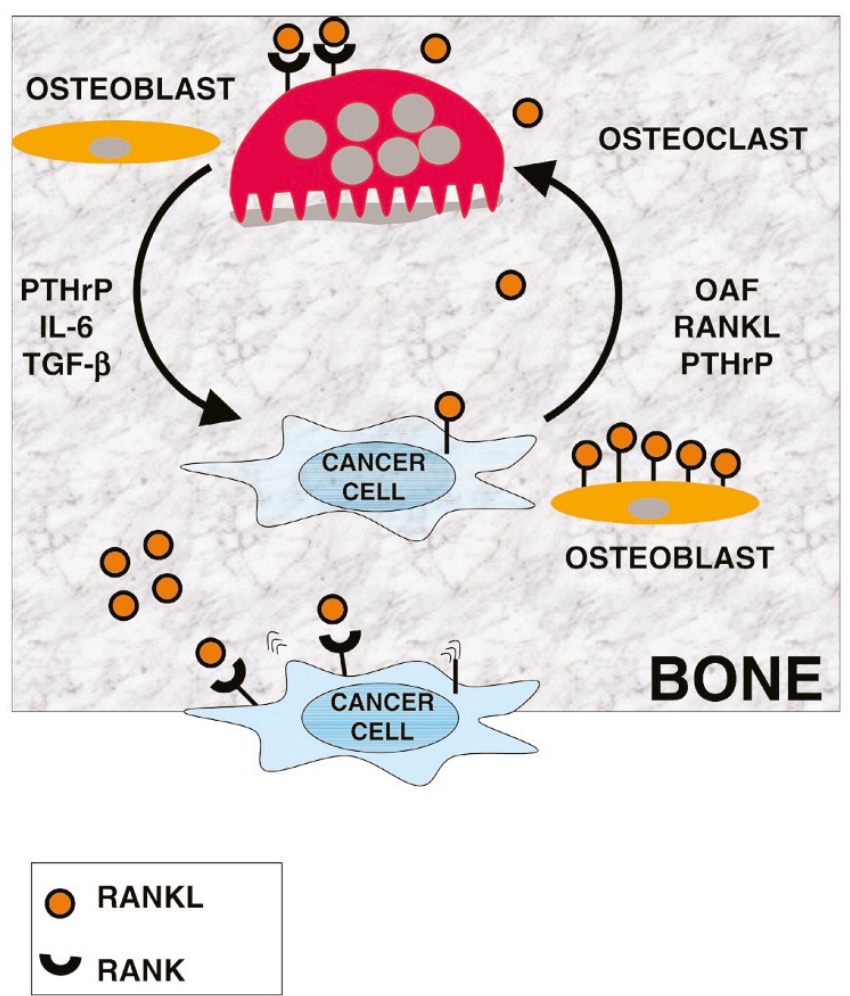

Breast cancer-bone interactions in skeletal metastasis using the receptor activator of NF- $\mathrm{KB}$ ligand (RANKL)/RANK pathway. Expression of RANK enables breast cancer cells to migrate to bone where the cognate ligand RANKL is abundantly expressed by osteoblasts. Some tumour cells express RANKL, whereas others further enhance RANKL expression by cell-to-cell contact of tumour cells with osteoblastic lineage cells. This enables breast cancer cells to enter a vicious circle where they stimulate bone-destroying osteoclasts that express RANK (first loop). Bone degradation by osteoclasts creates further space for expansive tumour growth within the bone microenvironment and releases a variety of growth factors and cytokines that have been deposited by osteoblasts, including parathyroid hormone-related peptide (PTHrP), IL-6, and transforminggrowth factor (TGF)- $\beta$, and that serve as tumour survival factors (second loop). OAF, osteoclast activating factor.

expressed [8]. The correlation of high RANK expression with osteotropism in murine models was demonstrated across diverse tumour cell types, including breast cancer and melanoma [8]. Blocking RANKL-RANK signalling in these mice by OPG administration reduced the skeletal tumour burden by $50 \%$ and prevented tumour-induced paralysis [8].

What are the clinical lessons to be learned from these discoveries? The ménage à trois of breast cancer cells, osteoblasts, and osteoclasts is linked through the RANKL/ RANK/OPG system, which explains why tumour cells home to bone and later on destroy it. It will be important to know whether high-risk patients for skeletal metastases can be identified based on high RANK expression in their primary breast tumours. Currently, women with skeletal metastases due to breast cancer are treated by chemotherapy, radiotherapy, and intravenous bisphosphonates, or combinations thereof. Of these, bisphosphonates inhibit certain osteoclast functions and promote osteoclast apoptosis. Recently, a fully human monoclonal antibody against RANKL (denosumab) has been developed and is currently being evaluated in clinical trials. Denosumab interferes with RANK signalling by blocking RANKL and, just like OPG, preventing RANK activation. Denosumab protected against bone loss in postmenopausal women with low bone mass based on biochemical markers of bone turnover and measurements of bone mineral density [9]. Moreover, RANKL inhibition also suppressed biochemical markers of bone turnover and skeletal-related events such as fractures, spinal cord compression, or the need to perform surgery or radiotherapy in women with breast cancer [10]. Long-term data on denosumab will show whether our detailed knowledge of bone cell biology and the RANKL/RANK pathway can be translated to prevent skeletal migration and metastases in women suffering from breast cancer.

\section{Competing interests}

The authors declare that they have no competing interests.

\section{References}

1. Roodman GD: Mechanisms of bone metastasis. $N$ Engl J Med 2004, 350:1655-1664.

2. Anderson DM, Maraskovsky E, Billingsley WL, Dougall WC, Tometsko ME, Roux ER, Teepe MC, DuBose RF, Cosman D, Galibert L: A homologue of the TNF receptor and its ligand enhance T-cell growth and dendritic-cell function. Nature 1997, 390:175-179.

3. Lacey DL, Timms E, Tan HL, Kelley MJ, Dunstan CR, Burgess T, Elliott R, Colombero A, Elliott G, Scully S, Hsu H, Sullivan J, Hawkins N, Davy E, Capparelli C, Eli A, Oian YX, Kaufman S, Sarosi I, Shalhoub V, Senaldi G, Guo J, Delaney J, Boyle WJ: Osteoprotegerin ligand is a cytokine that regulates osteoclast differentiation and activation. Cell 1998, 93:165-176.

4. Simonet WS, Lacey DL, Dunstan CR, Kelley M, Chang MS, Luthy $\mathrm{R}$, Nguyen $\mathrm{HQ}$, Wooden S, Bennett L, Boone T, Shimamoto G, DeRose M, Elliott R, Colombero A, Tan HL, Trail G, Sullivan J, Davy E, Bucay N, Renshaw-Gegg L, Hughes TM, Hill D, Pattison W, Campbell P, Sander S, Van G, Tarpley J, Derby P, Lee R, Boyle WJ: Osteoprotegerin: a novel secreted protein involved in the regulation of bone density. Cell 1997, 89:309-319.

5. Thomas RJ, Guise TA, Yin JJ, Elliott J, Horwood NJ, Martin TJ, Gillespie MT: Breast cancer cells interact with osteoblasts to support osteoclast formation. Endocrinology 1999, 140:44514458.

6. Morony S, Capparelli C, Sarosi I, Lacey DL, Dunstan CR Kostenuik PJ: Osteoprotegerin inhibits osteolysis and decreases skeletal tumor burden in syngeneic and nude mouse models of experimental bone metastasis. Cancer Res 2001, 61:4432-4436.

7. Fata JE, Kong YY, Li J, Sasaki T, Irie-Sasaki J, Moorehead RA, Elliott R, Scully S, Voura EB, Lacey DL, Boyle WJ, Khokha R, Penninger JM: The osteoclast differentiation factor osteoprotegerin-ligand is essential for mammary gland development. Cell 2000, 103:41-50.

8. Jones $\mathrm{DH}$, Nakashima T, Sanchez $\mathrm{OH}$, Kozieradzki I, Komarova SV, Sarosi I, Morony S, Rubin E, Sarao R, Hojilla CV, Komnenovic V, Kong YY, Schreiber M, Dixon SJ, Sims SM, Khokha R, Wada T, Penninger JM: Regulation of cancer cell migration and bone metastasis by RANKL. Nature 2006, 440:692-696.

9. McClung MR, Lewiecki EM, Cohen SB, Bolognese MA, Woodson GC, Moffett AH, Peacock M, Miller PD, Lederman SN, Chesnut $\mathrm{CH}$, Lain D, Kivitz AJ, Holloway DL, Zhang C, Peterson MC, 
Bekker PJ; AMG 162 Bone Loss Study Group: Denosumab in postmenopausal women with low bone mineral density. $N$ Engl J Med 2006, 354:821-831.

10. Lipton A, Steger GG, Figueroa J, Alvarado C, Solal-Celigny P, Body JJ, de Boer R, Berardi R, Gascon P, Tonkin KS, et al.: Randomized active-controlled phase II study of denosumab efficacy and safety in patients with breast cancer-related bone metastases. J Clin Oncol 2007, 25:4431-4437. 